\title{
Differential effects of spinal cord transection on glycinergic and GABAergic synaptic signaling in sub-lesional lumbar motoneurons.
}

\author{
Helene Bras ${ }^{1}$ and Sylvie Liabeuf ${ }^{1}$ \\ ${ }^{1}$ Institut de Neurosciences de la Timone, UMR 7289, CNRS and Aix Marseille Université, Campus \\ Santé Timone, 13385, Marseille, France.
}

Corresponding author: Hélène Bras: helene.bras@univ-amu.fr

\begin{abstract}
This review takes stock on the impact of complete spinal cord transection (SCT) on the plasticity of the inhibitory synaptic transmission on sub-lesional lumbar motoneurons (MNs), differentiating between studies in neonate and adult rats.

After neonatal SCT, normal maturational up-regulation of glycine receptors was observed. On the other hand, the developmental downregulation of the $\mathrm{GABA}_{\mathrm{A}}$ receptors, as well as the upregulation of the co-transporter $\mathrm{KCC} 2$, but not the normal decrease of NKCC1, were prevented. In adult SCT rats, glycinergic synaptic transmission, which is the major contributor to spinal MNs inhibition in adulthood, had normal control levels 2 months post-injury. On the other hand, the GABAergic transmission was altered through an up-regulation of the pre-signaling levels and a down-regulation in the density of post synaptic receptors. $\mathrm{KCC} 2$ membrane expression was down-regulated at all post-injury times tested ( $24 \mathrm{~h}$ to 4 months), thereby depolarizing the $\mathrm{Cl}-$ equilibrium potential and reducing the strength of postsynaptic inhibition.

The preservation of glycinergic pre- and post signaling, is probably a key factor in the success of locomotor rehabilitation programs in adult SCT rats. However, these data highlight the need to develop strategies to restore $\mathrm{KCC} 2$ levels in lumbar $\mathrm{MNs}$, to stabilize the excitation/inhibition balance, which is essential to the effective control of skeletal muscle activity.
\end{abstract}

\section{Highlights}

- Rats with complete spinal cord transection (SCT) are unambiguous models of paraplegia.

- We review the plasticity of inhibition on spinal MNs in neonate $v s$ adult SCT rats.

- In both models, glycinergic pre- and post-synaptic signalings were normal. 
- On the contrary, the levels $\mathrm{GABA}_{\mathrm{A}} \mathrm{R}$ and $\mathrm{KCC} 2$ were dysregulated.

- After SCT, KCC2 levels must be restored to increase glycinergic inhibition strength.

\section{Introduction}

More than 53\% of patients with traumatic spinal cord injury are paraplegic. This justifies the use of rats with low thoracic spinal cord transection (SCT) rats, unambiguous models of paraplegia, to study the plasticity of the neural networks below the lesion (Edgerton et al., 2001; Rossignol, 2006). Among the changes resulting from the loss of supra-spinal descending inputs in SCT rats, alterations in inhibitory synaptic transmission to lumbar motoneurons (MNs), mediated by glycine receptors (GlyR) and $\gamma$-aminobutyric acid receptors $\left(\mathrm{GABA}_{\mathrm{A}} \mathrm{R}\right.$ ) (for reviews see (Fritschy, 2015; Legendre, 2001)), have been the subject of several studies over the last 20 years. They include changes in size and density of pre-synaptic inhibitory inputs (glycinergic and/or GABAergic) (Edgerton et al., 2001; Ichiyama et al., 2011; Khalki et al., 2018), post-synaptic expression of GlyR and $\mathrm{GABA}_{\mathrm{A}} \mathrm{R}$ subunits (Edgerton et al., 2001; Khristy et al., 2009; Sadlaoud et al., 2020; Sadlaoud et al., 2010), anchoring protein gephyrin (Edgerton et al., 2001; Sadlaoud et al., 2010), and cation chloride co-transporters KCC2 (and/or NKCC1) that regulate intracellular chloride levels required for inhibition (Bos et al., 2013; Boulenguez et al., 2010; Chopek et al., 2015; Cote et al., 2014; Jean-Xavier et al., 2006; Khalki et al., 2018; Liabeuf et al., 2017). However, the variability of the experimental procedures and particularly of the onset of the lesion (cord-transected neonates $v s$ adults) and the post-lesional delays, prevent a clear overview of the time course of this alteration. The purpose of the present work is to take stock of these data, based on the works in the literature listed in Table 1. Although some early studies have been done in SCT cats (Tillakaratne et al., 2002; Tillakaratne et al., 2000), only those done in SCT rats, which are the majority, have been considered here.

Developmental membrane expression of GlyR and $G A B A_{A} R$ in spinal MNs: Glycinergic ionotropic receptors form pentameric transmembrane quaternary structure. In fetal rat spinal cord neurons, GlyRs have a dominant homomeric form composed of $5 \alpha 2$ subunits. Expression of $\alpha 2$ subunits decreases after birth, in favour of $\alpha 1$ expression, and GlyR becomes heteromeric with an invariant stoichiometry of $3 \alpha / 2 \beta$ (Legendre, 2001). During development, the density of GlyR increased from P1 to P7 (See Fig. 1) to reach a plateau that remains stable at P12 (Sadlaoud et al., 2010). In adults, glycine and strychnine bind to $\alpha$ subunits only (Legendre, 2001). 
$\mathrm{GABA}_{\mathrm{A}}$ Rs form pentameric complexes assembled from a family of at least 15 subunits $(\alpha 1-6$, $\beta 1-3, \gamma 1-3, \delta, \rho 1-2$, (Bohlhalter et al., 1996)). GABA $A_{A}$ Rs are expressed early during ontogeny (E13), and $\alpha 1, \alpha 2, \alpha 3$ and $\alpha 5$ mRNAs are detected in the embryonic spinal cord (Ma et al., 1993). At $\mathrm{P} 1$, only the $\mathrm{GABA}_{\mathrm{A}} \mathrm{R} \alpha 2$ and $\mathrm{GABA}_{\mathrm{A}} \mathrm{R} \alpha 3$ remain expressed on the spinal motoneuronal membrane (Sadlaoud et al., 2010). During the first postnatal week, the expression of both subunits decreases but they are still observed in juvenile animals (P12), with a ratio of 5 GlyR $\alpha 1$ to $1 \mathrm{GABA}_{\mathrm{A}} \mathrm{R} \alpha 2, \alpha 3$ (Sadlaoud et al., 2010). In the mature spinal cord, the $\alpha 2 \beta 3 \gamma 2$ and $\alpha 3 \beta 3 \gamma 2$ combinations are preponderant (Fritschy and Brunig, 2003). The $\alpha$ and $\beta$ subunits of the $\mathrm{GABA}_{\mathrm{A}} \mathrm{R}$ are required for GABA binding, and the $\alpha$ subunits determines the kinetics of deactivation and/or desensitization of the channel properties (Gingrich et al., 1995). The coassembly of $\gamma$ with $\alpha$ sub-units is required for benzodiazepine binding (Khristy et al., 2009).

\section{Membrane expression of GlyR and $G A B A_{A} R$ in spinal MNs after neonatal SCT: After} neonatal SCT (P0), normal densities of GlyR $\alpha 1$ were observed in the plasma membrane of triceps surae (TS) MNs at P7 (Sadlaoud et al., 2010). On the contrary, the developmental downregulation of the $\alpha 2$ and $\alpha 3$ subunits of the $\mathrm{GABA}_{\mathrm{A}} \mathrm{R}$ was prevented (Sadlaoud et al., 2010) (see Fig.1), whereas the $\mathrm{GABA}_{\mathrm{A}} \mathrm{R} \gamma 2$ was down-regulated in soleus MNs and upregulated in tibialis anterior (TA) MNs (Khristy et al., 2009). Moreover, the up-regulation of KCC2 normally observed from P0 to P7 was prevented after neonatal SCT in the region of MNs (Jean-Xavier et al., 2006) as well as on TS MNs (Bos et al., 2013). SCT eliminates the major supra spinal source of $5 \mathrm{HT}$, and only $2-15 \%$ of the 5 -HT levels remain below the lesion, partly due to intrinsic spinal 5-HT neurons (Kong at al 2010). 5-HT2A receptors expression increases after SCI (Kong at al 2010) and their activation with the specific agonist TCB2 leads to the restoration of KCC2 expression (Bos et al 2013). In neonatal SCT rats treated with DOI, a nonselective agonist of 5- $\mathrm{HT}_{2 \mathrm{~A}}$, в and $\mathrm{C}$ receptors, GlyR $\alpha 1$ expression remained stable, while that of $\mathrm{GABA}_{\mathrm{A}} \mathrm{R}$ (Sadlaoud et al., 2010) as well as KCC2 (Bos et al., 2013) returned to control values. Interestingly, 5- $\mathrm{HT}_{2 \mathrm{~B}} \mathrm{Rs}$ and $5-\mathrm{HT}_{2} \mathrm{CRs}$, but not 5- $\mathrm{HT}_{2 \mathrm{~A}} \mathrm{Rs}$ become constitutively active (spontaneously active without 5-HT) after SCI (Murray et al., 2010) and this constitutive activity may be partly responsible for the depolarizing shift of the chloride equilibrium potential after SCI (Bos et al., 2013). This suggested that the plasticity of GlyR is independent of supraspinal influences whereas that of $\mathrm{GABA}_{\mathrm{A}} \mathrm{R}$ and $\mathrm{KCC} 2$ is markedly influenced by descending pathways, in particular serotonergic projections (Jean-Xavier et al., 2006; Sadlaoud et al., 2010). 
Membrane expression of GlyR and $G A B A_{A} R$ in spinal MNs of adult SCT rats: In rats transected as adults, the expression of glycinergic and GABAergic synaptic signaling followed different time courses. The acute post-lesion phase was marked by an unstable temporal and spatial pattern of alterations in GlyR1-3 mRNA expression with different levels of up or down regulation occurring within 6h to 10 days after lesion (Esmaeili and Zaker, 2011). In the early chronic phase, 3 weeks post-injury, the levels of expression of GlyR $\alpha 1$ were significantly lower than in controls (Sadlaoud et al., 2020). This is related to inflammatory responses, as early treatment with the corticosteroid methylprednisolone allows a return to normal values. This down-regulation of the levels of GlyR $\alpha 1$ was transitory, since at later times ( 8 weeks postlesion), GlyR $\alpha 1$ expression had normal control values in both TA and gastrocnemius (GS) MNs (Sadlaoud et al., 2020). In this post-injury period, the density and size of pre-synaptic glycinergic inputs apposed on GS and TA MNs also displayed normal values (Khalki et al., 2018), suggesting a matching between pre-synaptic inputs and post-synaptic membrane receptors, which is a prerequisite for efficient synaptic transmission (Lardi-Studler and Fritschy, 2007). Note that after very long post-injury periods (16 weeks), the expression of GlyR $\alpha 1$ was significantly lower than in controls, in both TA and GS MNs (Sadlaoud et al., 2020).

In adult SCT rats, the sub-lesional spinal GABAergic synaptic system was differently affected than the glycinergic one. Three weeks after SCT, a down-regulation of GABA $\mathrm{A}_{\mathrm{R}}$ occurred, and could not be reversed by treatment with the anti-inflammatory methylprednisolone (Sadlaoud et al., 2020). Then, at longer times post-injury ( 8 and 16 weeks) the levels of GABA $R$ at the membrane of GS and TA MNs remained significantly lower than in intact controls (Sadlaoud et al., 2020). In this time window (11 weeks post-injury) an increase in the densities of GABAergic axon terminals apposed on lumbar MNs has been reported (Khalki et al., 2018). Therefore, we are in the presence of a drastic mismatch between pre-synaptic and post-synaptic specializations, which suggests an impairment of the GABAergic synaptic transmission to sublesional MNs, from early to late chronic phase post-injury.

In summary, these data suggest that SCT differentially affects the two inhibitory neurotransmissions to lumbar MNs caudal to the lesion, whether the lesion is done at birth or in adults. The glycinergic system remains relatively stable, at least up to 2 months post-injury, whereas the GABAergic transmission is strongly altered. In the other hand, SCT prevents the maturational up-regulation of KCC2 expression in neonate rats (Bos et al., 2013; Jean-Xavier et al., 2006) and results in a down-regulation of KCC2 levels in MNs of adult rats (Boulenguez 
et al., 2010; Chopek et al., 2015; Cote et al., 2014; Khalki et al., 2018), thereby depolarizing the $\mathrm{Cl}-$ equilibrium potential and reducing the strength of post-synaptic inhibition (see Figure 1) and contributing to spasticity (Boulenguez et al., 2010).

Functional considerations: Since GlyR expression returns to control levels by 2 months postlesion, one would expect improvement of the hindlimb function at this stage. However, no spontaneous locomotor recovery could be observed in adult SCT rats (Alluin et al., 2015). At all post-injury times tested $(1,7,15,21,28$ and 45 days, 8 and 11 weeks, 3 and 4 months, see Table 1) there was a down regulation of the levels of KCC2 in sub-lesional MNs. Note that the expression rates of $\mathrm{NKCC} 1$, which decreases from P5 to low levels in adult spinal MNs (Still et al. 2009), are not significantly affected by SCI in adult rats (Boulenguez et al., 2010; Cote et al., 2012). A restoration of KCC2 levels has been observed in SCT adult rats using sensorimotor strategies (Chopek et al., 2015; Cote et al., 2014; Khalki et al., 2018) or pharmacological treatments with the KCC2 activator prochlorperazine (Liabeuf et al., 2017) or the calpain inhibitor MDL28170 (Plantier et al., 2019). The effect of this up-regulation is twofold. It allows 1) a strengthening of inhibition through the preserved GlyR and chloride homeostasis and 2) a decrease of MNs hyperexcitability which resulted from the up-regulation of the persistent sodium current (INap) responsible for spasms (Brocard et al., 2016; Plantier et al., 2019). Therefore, the post lesional preservation of the glycinergic synaptic system, which is the major contributor to spinal MNs inhibition in adult (Gao et al., 2001; Khalki et al., 2018), is undoubtedly one of the factors that makes the locomotor rehabilitation possible in SCT adult rats. However, the search for strategies for restoring KCC2 levels, to maintain the chloride homeostasis and reduce the imbalance between excitation and inhibition, is a major issue to alleviate motor disorders affecting individuals with spinal cord injury, such as spasticity. 


\begin{tabular}{|c|c|c|c|c|c|c|c|c|c|}
\hline Study & Animal & Detection & Lesion & $\begin{array}{c}\text { Lesion } \\
\text { onset }\end{array}$ & $\begin{array}{c}\text { Post lesional } \\
\text { delay }\end{array}$ & $\begin{array}{l}\text { studied regions } \\
\text { (targets) }\end{array}$ & $\begin{array}{c}\text { pre-synaptic } \\
\text { signaling } \\
\text { (inputs) onto } \\
\text { MNs }\end{array}$ & $\begin{array}{c}\text { post synaptic } \\
\text { signaling }(M N)\end{array}$ & $\begin{array}{l}\text { Expression/levels \% } \\
\text { controls }\end{array}$ \\
\hline \multirow{2}{*}{$\begin{array}{l}\text { Edgerton et } \\
\text { al., } 2001\end{array}$} & \multirow{2}{*}{ rat } & \multirow{2}{*}{ WesternBlot } & \multirow{2}{*}{ SCT } & \multirow{2}{*}{ P7 } & \multirow{2}{*}{2 weeks } & & & GlyR $\alpha 1$ & up-regulated \\
\hline & & & & & & & & Gephyrin & up-regulated \\
\hline \multirow{2}{*}{$\begin{array}{l}\text { Khristy et al., } \\
2009\end{array}$} & \multirow{2}{*}{ rat } & \multirow{2}{*}{ IHF } & \multirow{2}{*}{$\mathrm{SCT}$} & \multirow{2}{*}{ P5 } & \multirow{2}{*}{3 month } & Soleus MNs & & $\mathrm{GABA}_{\mathrm{A}} \mathrm{R} \gamma 2$ & down-regulated \\
\hline & & & & & & TA MNs & & $\mathrm{GABA}_{\mathrm{A}} \mathrm{R} \gamma 2$ & up-regulated \\
\hline $\begin{array}{l}\text { Jean-Xavier } \\
\text { et al. } 2006\end{array}$ & rat & IHF & $\mathrm{SCT}$ & P0 & 7 days & $\begin{array}{l}\text { MNs pool (L4 } \\
\text { segment) }\end{array}$ & & $\mathrm{KCC} 2$ & down-regulated \\
\hline \multirow{5}{*}{$\begin{array}{l}\text { Sadlaoud et } \\
\text { al. } 2010\end{array}$} & \multirow{5}{*}{ rat } & \multirow{5}{*}{ IHF } & \multirow{5}{*}{$\mathrm{SCT}$} & \multirow{3}{*}{ P0 } & \multirow{3}{*}{7 days } & \multirow{3}{*}{ TS MNs } & & GlyR $\alpha 1$ & no change \\
\hline & & & & & & & & $\mathrm{GABA}_{\mathrm{A}} \mathrm{R} \alpha 2$ & up-regulated \\
\hline & & & & & & & & $\mathrm{GABA}_{\mathrm{A}} \mathrm{R} \alpha 3$ & up-regulated \\
\hline & & & & \multirow[b]{2}{*}{ P5 } & \multirow[b]{2}{*}{7 days } & \multirow[b]{2}{*}{ TS MNs } & & GlyR $\alpha 1$ & no change \\
\hline & & & & & & & & $\begin{array}{l}\mathrm{GABA}_{\mathrm{A}} \mathrm{R} \alpha 2 \\
\mathrm{GABA}_{\Delta} \mathrm{R} \alpha 3\end{array}$ & $\begin{array}{l}\text { up-regulated } \\
\text { up-regulated }\end{array}$ \\
\hline $\begin{array}{l}\text { Ichiyama et } \\
\text { al., } 2011\end{array}$ & rat & $\begin{array}{l}\text { electron } \\
\text { microscopy }\end{array}$ & $\mathrm{SCT}$ & P5 & 16 days & $\alpha$ and $\gamma$ TA MNs & $\begin{array}{l}\text { S-type boutons } \\
\text { F-type boutons } \\
\text { C-type boutons } \\
\text { M-type boutons }\end{array}$ & & $\begin{array}{l}\text { Proportion of inhibitory to } \\
\text { excitatory boutons } \\
\text { increased in both } \mathrm{MNs}\end{array}$ \\
\hline $\begin{array}{l}\text { Bos et al., } \\
2013 \\
\end{array}$ & rat & IHF, WB & $\mathrm{SCT}$ & P0 & 7 days & TS MNs & & $\mathrm{KCC} 2$ & down-regulated \\
\hline Tillakaratne & cat & JHE ISH WP & SCT & adult & 369 months & lumbar crev matter & GAD67 & & up-regulated \\
\hline et al. 2000 & cat & IIIF, ISH, WD & $S C 1$ & aduit & $3,0,9$ montusis & iundodr grey milter & GAD65 & & no change \\
\hline $\begin{array}{l}\text { Tillakaratne } \\
\text { et al } 2002\end{array}$ & cat & $\mathrm{IHC}, \mathrm{ISH}, \mathrm{WB}$ & $\mathrm{SCT}(\mathrm{T} 12)$ & adult & 3 to 25 months & $\begin{array}{l}\text { LIX neurons (L5- } \\
\text { L7 segments) }\end{array}$ & GAD67 & & up-regulated \\
\hline & & & & & $24 \mathrm{~h}$ & & & & $8 \%$ decrease \\
\hline Boulenguez & rat & IHF, WB & SCT & adult & 7 days & lumbar MNs & & & $10 \%$ decrease \\
\hline et al., 2010 & rat & $\mathrm{IHF}, \mathrm{WB}$ & $\mathrm{SCT}$ & adult & 15 days & lumbar MNs & & $\mathrm{KCC} 2$ & $19 \%$ decrease \\
\hline & & & & & 45 days & & & & $22 \%$ decrease \\
\hline $\begin{array}{l}\text { Esmaeili and } \\
\text { Zaker } 2011\end{array}$ & rat & $\begin{array}{c}\text { real time reverse } \\
\text { transcription PCR }\end{array}$ & $\mathrm{SCT}$ & adult & $6 \mathrm{~h}, 24 \mathrm{~h}, 3 \mathrm{j}, 7 \mathrm{j}, 10 \mathrm{j}$ & $\begin{array}{l}\text { spinal cord } 2,5 \mathrm{~cm} \\
\text { pre and post lesion } \\
\text { site }\end{array}$ & & $\begin{array}{l}\text { GlyR1 mRNA, } \\
\text { GlyR2 mRNA, } \\
\text { GlyR3 mRNA }\end{array}$ & $\begin{array}{l}\text { up regulate } 7 \text { day PL, } \\
\text { down regulated, } \\
\text { up regulated } 3 \text { days PL }\end{array}$ \\
\hline Coté et al., & rat & WB & SCT & adult & 28 davs & lumbar seoment & & NKCC1 & no change \\
\hline 2014 & rat & WB & SCl 1 & adult & 28 days & lumbar segment & & $\mathrm{KCC} 2$ & down-regulated \\
\hline Chopek et al. & rat & qRT-PCR & SCT & adult & 3 months & GS, Soleus MNs & & $\mathrm{KCC} 2$ & no significant change \\
\hline 2015 & & mRNA & & & & TA, EDL MNs & & $\mathrm{KCC} 2$ & $20 \%$ decrease \\
\hline $\begin{array}{l}\text { Liabeuf et al. } \\
2017\end{array}$ & rat & IHF & SCT & adult & 3 weeks & lumbar MNs & & $\mathrm{KCC} 2$ & $20 \%$ decrease \\
\hline & & & & & & GS MNs & GABA boutons & & up-regulated \\
\hline & & & & & & TA MNs & GABA boutons & & up-regulated \\
\hline $\begin{array}{c}\text { Khalki et al., } \\
2018\end{array}$ & rat & IHF & $\mathrm{SCT}$ & adult & 11 weeks & GS MNs & Glvcine boutons & & no change \\
\hline & & & & & & TA MNs & Glycine boutons & & no change \\
\hline & & & & & & & & $\mathrm{KCC} 2$ & $30 \%$ decrease \\
\hline & & & & & & TAMNs & & GlyR $\alpha 1$ & down-regulated \\
\hline & & & & & 3 weoks & TA MNs & & $\mathrm{GABA}_{\mathrm{A}} \mathrm{R} \beta 2,3$ & down-regulated \\
\hline & & & & & 3 weeks & GS MNs & & GlyR $\alpha 1$ & down-regulated \\
\hline & & & & & & GS MNS & & $\mathrm{GABA}_{\mathrm{A}} \mathrm{R} \beta 2,3$ & down-regulated \\
\hline & & & & & & TA MNs & & GlyR $\alpha 1$ & no change \\
\hline Sadlaoud et & rat & JHF & SCT & adult & 8 weeks & TA MNs & & $\mathrm{GABA}_{\mathrm{A}} \mathrm{R} \beta 2,3$ & down-regulated \\
\hline $\begin{array}{l}\text { al. } 2020 \text { (In } \\
\text { press) }\end{array}$ & rat & $1 \mathrm{HF}$ & Sct 1 & aduit & 8 weeks & GS MNs & & GlyR $\alpha 1$ & no change \\
\hline & & & & & & GS MNs & & $\mathrm{GABA}_{\mathrm{A}} \mathrm{R} \beta 2,3$ & down-regulated \\
\hline & & & & & & TA MNIs & & GlyR $\alpha 1$ & down-regulated \\
\hline & & & & & 16 weeks & TA MNs & & $\mathrm{GABA}_{\mathrm{A}} \mathrm{R} \beta 2,3$ & down-regulated \\
\hline & & & & & 16 weeks & GS Mns & & GlyR $\alpha 1$ & down-regulated \\
\hline & & & & & & GS Mns & & $\mathrm{GABA}_{\mathrm{A}} \mathrm{R} \beta 2,3$ & down-regulated \\
\hline Table 1 & & & & & & & & & \\
\hline & & & & & & & & & \\
\hline
\end{tabular}

Table 1: Summary of literature data on the effect of SCT on the inhibitory pre- and postsynaptic signaling. IHF: Immunohistofluorescence; IHC: immunohistochemistry; ISH: In situ hybrydation; WB: Western blot; SCT: Complete spinal cord transection; MN: Motoneuron; TA: Tibialis anterior; GS: Gastrocnemius; TS: Triceps surae 

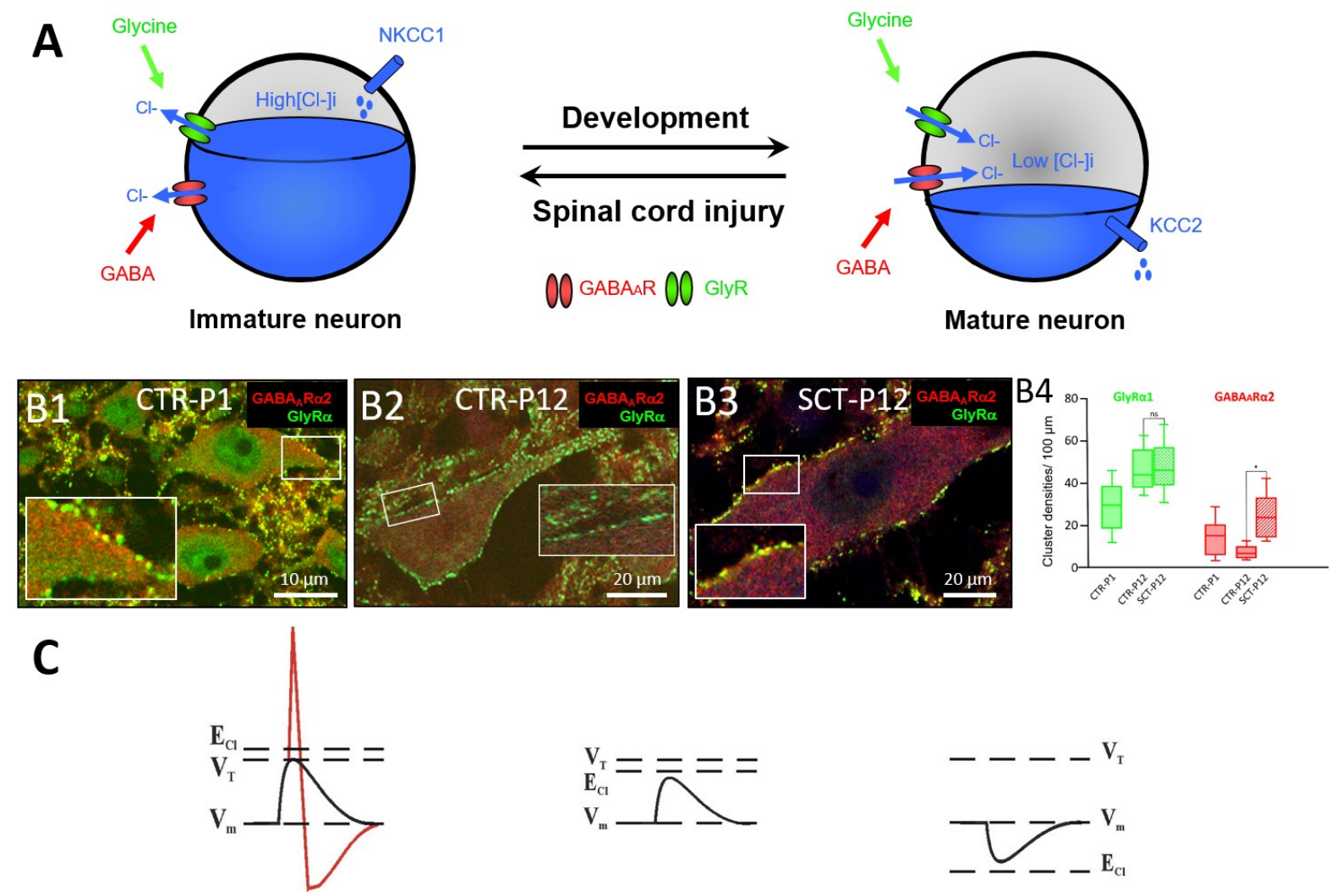

Figure 1: Regulation of intracellular $\mathrm{Cl}-$ concentration during development and after spinal cord injury. A) The two inhibitory neurotransmitters glycine and GABA act through glycine and $\mathrm{GABA}_{\mathrm{A}}$ receptors (GlyR and $\left.\mathrm{GABA}_{\mathrm{A}} \mathrm{R}\right)$, respectively. Cation-chloride $(\mathrm{Cl}-)$ cotransporters $\mathrm{NKCC} 1$ (Cl- intruder) and $\mathrm{KCC} 2$ (Cl- extruser) are responsible for the regulation of intracellular chloride concentration ([Cl-]i). B) Dual immunohistochemistry of GlyR $\alpha 1$ and $\mathrm{GABA}_{\mathrm{A}} \mathrm{R} \alpha 2$ on identified TA MNs in control (CTR) rats at P1 (B1), during development and on juvenile control rats (P12; B2), and P12 rats transected at P7 (SCT-12; B3). B4: Histograms of the densities of GlyR $\alpha 1$ and GABA ${ }_{A} R 2$ per $100 \mu \mathrm{m}$ of somatic motoneuronal membrane, quantified in CTR-P1, CTR-P12 and SCT-P12, respectively. Adapted from (Sadlaoud et al., 2010). C) In immature neurons, [Cl-]i is high and the equilibrium potential of $\mathrm{Cl}-(\mathrm{ECl})$ is above the resting membrane potential $(\mathrm{Vm})$. Activation of GlyR and GABA $\mathrm{R}$ leads to depolarization and may even trigger cell firing when $\mathrm{ECl}$ is above action potential threshold (VT). During development, because of the down-regulation of NKCC1 and up-regulation of $\mathrm{KCC} 2,[\mathrm{Cl}-] \mathrm{i}$ decreases, ECl shifts to values below $\mathrm{Vm}$. As a result, the strength of postsynaptic inhibition increases. Spinal cord transection rapidly transforms the actions of GABA and glycine from inhibition to excitation, by increasing the $\left[\mathrm{Cl}^{-}\right] \mathrm{i}$ via downregulation of $\mathrm{KCC} 2$. Adapted from (Vinay and Jean-Xavier, 2008).

Acknowledgments: This work was supported by INSERM and CNRS. 


\section{Literature Cited}

Alluin, O., Delivet-Mongrain, H., Rossignol, S., 2015. Inducing hindlimb locomotor recovery in adult rat after complete thoracic spinal cord section using repeated treadmill training with perineal stimulation only. J. Neurophysiol 114, 1931-1946.

Bohlhalter, S., Weinmann, O., Mohler, H., Fritschy, J.M., 1996. Laminar compartmentalization of GABAA-receptor subtypes in the spinal cord: an immunohistochemical study. J Neurosci 16, 283-297. Bos, R., Sadlaoud, K., Boulenguez, P., Buttigieg, D., Liabeuf, S., Brocard, C., Haase, G., Bras, H., Vinay, L., 2013. Activation of 5-HT2A receptors upregulates the function of the neuronal $\mathrm{K}-\mathrm{Cl}$ cotransporter KCC2. Proc Natl Acad Sci U S A 110, 348-353.

Boulenguez, P., Liabeuf, S., Bos, R., Bras, H., Jean-Xavier, C., Brocard, C., Stil, A., Darbon, P., Cattaert, D., Delpire, E., Marsala, M., Vinay, L., 2010. Down-regulation of the potassium-chloride cotransporter KCC2 contributes to spasticity after spinal cord injury. Nat. Med 16, 302-307.

Brocard, C., Plantier, V., Boulenguez, P., Liabeuf, S., Bouhadfane, M., Viallat-Lieutaud, A., Vinay, L., Brocard, F., 2016. Cleavage of $\mathrm{Na}(+)$ channels by calpain increases persistent $\mathrm{Na}(+)$ current and promotes spasticity after spinal cord injury. Nat. Med 22, 404-411.

Chopek, J.W., Sheppard, P.C., Gardiner, K., Gardiner, P.F., 2015. Serotonin receptor and KCC2 gene expression in lumbar flexor and extensor motoneurons posttransection with and without passive cycling. J Neurophysiol 113, 1369-1376.

Cote, M.P., Detloff, M.R., Wade, R.E., Jr., Lemay, M.A., Houle, J.D., 2012. Plasticity in ascending long propriospinal and descending supraspinal pathways in chronic cervical spinal cord injured rats. Front Physiol 3:330. doi: 10.3389/fphys.2012.00330. eCollection@2012., 330.

Cote, M.P., Gandhi, S., Zambrotta, M., Houle, J.D., 2014. Exercise modulates chloride homeostasis after spinal cord injury. J. Neurosci 34, 8976-8987.

Edgerton, V.R., Leon, R.D., Harkema, S.J., Hodgson, J.A., London, N., Reinkensmeyer, D.J., Roy, R.R., Talmadge, R.J., Tillakaratne, N.J., Timoszyk, W., Tobin, A., 2001. Retraining the injured spinal cord. J. Physiol 533, 15-22.

Esmaeili, A., Zaker, S.R., 2011. Differential expression of glycine receptor subunit messenger RNA in the rat following spinal cord injury. Spinal Cord 49, 280-284.

Fritschy, J.M., 2015. Significance of GABA(A) receptor heterogeneity: clues from developing neurons. Adv Pharmacol 73, 13-39.

Fritschy, J.M., Brunig, I., 2003. Formation and plasticity of GABAergic synapses: physiological mechanisms and pathophysiological implications. Pharmacol Ther 98, 299-323.

Gao, B.X., Stricker, C., Ziskind-Conhaim, L., 2001. Transition from GABAergic to glycinergic synaptic transmission in newly formed spinal networks. J Neurophysiol 86, 492-502.

Gingrich, K.J., Roberts, W.A., Kass, R.S., 1995. Dependence of the GABAA receptor gating kinetics on the alpha-subunit isoform: implications for structure-function relations and synaptic transmission. J Physiol 489 ( Pt 2), 529-543.

Ichiyama, R.M., Broman, J., Roy, R.R., Zhong, H., Edgerton, V.R., Havton, L.A., 2011. Locomotor training maintains normal inhibitory influence on both alpha- and gamma-motoneurons after neonatal spinal cord transection. J Neurosci 31, 26-33.

Jean-Xavier, C., Pflieger, J.F., Liabeuf, S., Vinay, L., 2006. Inhibitory postsynaptic potentials in lumbar motoneurons remain depolarizing after neonatal spinal cord transection in the rat. J Neurophysiol 96, 2274-2281.

Khalki, L., Sadlaoud, K., Lerond, J., Coq, J.O., Brezun, J.M., Vinay, L., Coulon, P., Bras, H., 2018. Changes in innervation of lumbar motoneurons and organization of premotor network following training of transected adult rats. Exp Neurol 299, 1-14.

Khristy, W., Ali, N.J., Bravo, A.B., de, L.R., Roy, R.R., Zhong, H., London, N.J., Edgerton, V.R., Tillakaratne, N.J., 2009. Changes in GABA(A) receptor subunit gamma 2 in extensor and flexor motoneurons and astrocytes after spinal cord transection and motor training. Brain Res 1273, 9-17. 
Lardi-Studler, B., Fritschy, J.M., 2007. Matching of pre- and postsynaptic specializations during synaptogenesis. Neuroscientist 13, 115-126.

Legendre, P., 2001. The glycinergic inhibitory synapse. Cell Mol Life Sci 58, 760-793.

Liabeuf, S., Stuhl-Gourmand, L., Gackiere, F., Mancuso, R., Sanchez Brualla, I., Marino, P., Brocard, F., Vinay, L., 2017. Prochlorperazine Increases KCC2 Function and Reduces Spasticity after Spinal Cord Injury. J Neurotrauma 34, 3397-3406.

Ma, W., Saunders, P.A., Somogyi, R., Poulter, M.O., Barker, J.L., 1993. Ontogeny of GABAA receptor subunit mRNAs in rat spinal cord and dorsal root ganglia. J Comp Neurol 338, 337-359.

Murray, K.C., Nakae, A., Stephens, M.J., Rank, M., D'Amico, J., Harvey, P.J., Li, X., Harris, R.L., Ballou, E.W., Anelli, R., Heckman, C.J., Mashimo, T., Vavrek, R., Sanelli, L., Gorassini, M.A., Bennett, D.J., Fouad, K., 2010. Recovery of motoneuron and locomotor function after spinal cord injury depends on constitutive activity in 5-HT2C receptors. Nat Med 16, 694-700.

Plantier, V., Sanchez-Brualla, I., Dingu, N., Brocard, C., Liabeuf, S., Gackiere, F., Brocard, F., 2019.

Calpain fosters the hyperexcitability of motoneurons after spinal cord injury and leads to spasticity.

Elife 8.

Rossignol, S., 2006. Plasticity of connections underlying locomotor recovery after central and/or peripheral lesions in the adult mammals. Philos. Trans. R. Soc. Lond B Biol. Sci 361, 1647-1671. Sadlaoud, K., Khalki, L., Brocard, F., Vinay, L., Boulenguez, P., Bras, H., 2020. Alteration of glycinergic receptor expression in lumbar spinal motoneurons is involved in the mechanisms underlying spasticity after spinal cord injury. J Chem Neuroanat 106, 101787.

Sadlaoud, K., Tazerart, S., Brocard, C., Jean-Xavier, C., Portalier, P., Brocard, F., Vinay, L., Bras, H., 2010. Differential plasticity of the GABAergic and glycinergic synaptic transmission to rat lumbar motoneurons after spinal cord injury. J. Neurosci 30, 3358-3369.

Tillakaratne, N.J., de Leon, R.D., Hoang, T.X., Roy, R.R., Edgerton, V.R., Tobin, A.J., 2002. Usedependent modulation of inhibitory capacity in the feline lumbar spinal cord. J. Neurosci 22, 31303143.

Tillakaratne, N.J., Mouria, M., Ziv, N.B., Roy, R.R., Edgerton, V.R., Tobin, A.J., 2000. Increased expression of glutamate decarboxylase (GAD(67)) in feline lumbar spinal cord after complete thoracic spinal cord transection. J. Neurosci. Res 60, 219-230.

Vinay, L., Jean-Xavier, C., 2008. Plasticity of spinal cord locomotor networks and contribution of cation-chloride cotransporters. Brain Res Rev 57, 103-110. 